\title{
Vacatures en instroom van apothekersassistenten op de arbeidsmarkt : van enquêtes naar prognoses
}

Citation for published version (APA):

Cörvers, F. (1997). Vacatures en instroom van apothekersassistenten op de arbeidsmarkt : van enquêtes naar prognoses. Researchcentrum voor Onderwijs en Arbeidsmarkt, Faculteit der Economische Wetenschappen. ROA Reports No. 8 https://doi.org/10.26481/umarep.1997008

Document status and date:

Published: 01/01/1997

DOI:

10.26481/umarep.1997008

Document Version:

Publisher's PDF, also known as Version of record

\section{Please check the document version of this publication:}

- A submitted manuscript is the version of the article upon submission and before peer-review. There can be important differences between the submitted version and the official published version of record.

People interested in the research are advised to contact the author for the final version of the publication, or visit the DOI to the publisher's website.

- The final author version and the galley proof are versions of the publication after peer review.

- The final published version features the final layout of the paper including the volume, issue and page numbers.

Link to publication

\footnotetext{
General rights rights.

- You may freely distribute the URL identifying the publication in the public portal. please follow below link for the End User Agreement:

www.umlib.nl/taverne-license

Take down policy

If you believe that this document breaches copyright please contact us at:

repository@maastrichtuniversity.nl

providing details and we will investigate your claim.
}

Copyright and moral rights for the publications made accessible in the public portal are retained by the authors and/or other copyright owners and it is a condition of accessing publications that users recognise and abide by the legal requirements associated with these

- Users may download and print one copy of any publication from the public portal for the purpose of private study or research.

- You may not further distribute the material or use it for any profit-making activity or commercial gain

If the publication is distributed under the terms of Article $25 \mathrm{fa}$ of the Dutch Copyright Act, indicated by the "Taverne" license above, 


\section{Vacatures en instroom van apothekersassistenten op de arbeidsmarkt: van enquêtes naar prognoses}

ROA-R-1997/8

F. Cörvers

Researchcentrum voor Onderwijs en Arbeidsmarkt

Faculteit der Economische Wetenschappen en Bedrijfskunde Universiteit Maastricht

Maastricht, november 1997 
ISBN 90-5321-219-1

SEC97.150/FC 


\section{Inhoud}

\section{Bladzijde}

1 Inleiding 1

2 Opzet en vraagstelling van de enquêtes $\quad 5$

3 Interpretatie van de enquête-resultaten $\quad 10$

4 Conclusies en aanbevelingen $\quad 19$

$\begin{array}{ll}\text { Literatuur } & 21\end{array}$

Bijlage 1 Enquête inzake meting vraag en aanbod apothekersassistenten 22

Bijlage 2 Vraagstelling aan MDGO-scholen over in- en uitstroom van leerlingen 


\section{Inleiding'}

Sedert 1989 worden door de Stichting Bedrijfsfonds Apotheken (SBA) een tweetal enquêtes gehouden om inzicht te krijgen in de actuele en toekomstige arbeidsmarktsituatie van apothekersassistenten: een vacature-enquête onder werkgevers van openbare apotheken en een enquête bij de opleidingsinstituten voor apothekersassistenten. Enerzijds tracht de SBA middels de vacature-enquête inzicht te krijgen in de aard en omvang van vacatures voor apothekersassistenten bij openbare apotheken. Anderzijds probeert de SBA bij opleidingsinstituten voor apothekersassistenten informatie te vergaren over de arbeidsmarktinstroom van gediplomeerde apothekersassistenten.

De resultaten van de vacature- en de instroom-enquêtes worden jaarlijks door de SBA gepubliceerd in vakbladen en het jaarverslag van de SBA. De SBA wil de enquêtes als instrumenten gebruiken bij het speerpunt van het beleid voor de komende jaren, namelijk de bevordering van de werkgelegenheid van apothekersassistenten ${ }^{2}$. In dit onderzoeksrapport wordt op verzoek van de SBA het huidige arbeidsmarktinstrumentarium van de SBA geëvalueerd. Het belang dat de SBA hecht aan het bevorderen van de werkgelegenheid van apothekersassistenten is ingegeven door de verslechterde arbeidsmarktsituatie van apothekersassistenten gedurende de laatste jaren ${ }^{3}$.

Daarnaast lijkt de arbeidsmarktsituatie voor apothekersassistenten onderhevig te zijn aan aanzienlijke fluctuaties, die voor een belangrijk deel hun oorzaak kunnen vinden in de nauwe aansluiting tussen opleiding en beroep voor apothekersassistenten ${ }^{4}$. De risico's van een nauwe aansluiting tussen opleiding en beroep doen zich voor zowel bij een aanbodtekort als bij een vraagtekort van apothekersassistenten. Bij een aanbodtekort hebben werkgevers geen goede mogelijkheden om schoolverlaters met een andere opleidingsachtergrond aan te nemen. Dit impliceert dat de substitutiemogelijkheden voor werkgevers in de sector apotheken bij een aanbodtekort beperkt zijn. Bij een vraagtekort zijn er voor afgestudeerde apothekersassistenten weinig mogelijkheden om een ander beroep dan apothekersassistent te vinden. Met andere woorden, de uitwijkmogelijkheden voor apothekersassistenten zijn beperkt bij een vraagtekort. Hierdoor zal de belangstelling voor de opleiding tot apothekersassistent afnemen, hetgeen op termijn weer zal leiden tot een tekortschietend aanbod. Het is derhalve van groot belang om de vinger aan de pols te houden bij de afstemming tussen vraag en

1. De auteur wil de heer E. Visser van de SBA, mevrouw T. van Rijn en mevrouw I. Keij van het CBS bedanken voor het verstrekken van de benodigde informatie over de vacature-enquêtes van de SBA en het CBS.

2. SBA (1996), Jaarverslag.

3. SBA (1996), Jaarverslag.

4. Zie het onderzoek dat eerder in opdracht van de SBA door het ROA (Van Smoorenburg en Van der Velden, 1996) is uitgevoerd. 
aanbod van personeel in de apotheeksector.

In dit rapport staat de vraag centraal of de vacature- en de instroom-enquêtes van de SBA de actuele en toekomstige arbeidsmarktsituatie van apothekersassistenten adequaat in beeld brengen. Voor de SBA is niet alleen de huidige, maar vooral ook de toekomstige arbeidsmarktsituatie van apothekersassistenten van belang, omdat toekomstige tekorten of overschotten aan apothekersassistenten mogelijkerwijs voorkomen kunnen worden door het voeren van een preventief arbeidsmarktbeleid dat gebaseerd is op middellange termijn prognoses.

De evaluatie van de enquêtes richt zich op zowel technische als inhoudelijke aspecten, waarbij de volgende drie onderzoeksvragen centraal staan.

1. Voldoet de opzet en de vraagstelling van de enquêtes aan de heersende inzichten voor het afnemen van dergelijke enquêtes?

Voor de toetsing van de opzet en de vraagstelling in de enquêtes zal worden verwezen naar de wetenschappelijke literatuur op dit gebied. Bij de bovengenoemde enquêtes zal onder meer aandacht worden besteed aan de eenduidigheid van het vacaturebegrip en de factoren die de respons van postenquêtes medebepalen.

2. In welke mate geven de enquêtes daadwerkelijk inzicht in het actuele tekort of overschot aan apothekersassistenten?

Uit het aantal openstaande vacatures voor apothekersassistenten en de arbeidsmarktinstroom van afgestudeerde apothekersassistenten is niet direct het tekort of overschot aan apothekerassistenten te bepalen. Hiervoor zijn meerdere factoren verantwoordelijk. Een belangrijke factor is zonder meer dat het weergegeven aantal vacatures in de vacature-enquête een moment-opname van de voorraad vacatures is, terwijl voor de arbeidsmarktinstroom van nieuwkomers op de arbeidsmarkt in feite stroomcijfers zijn vereist, die weergeven hoeveel banen er in een bepaalde periode vrijkomen (zgn. baanopeningen, zie hoofdstuk 4). Vanwege de zogenaamde zoekduur voor zowel werkgevers als werknemers wordt een vacature meestal pas na enige tijd vervuld, zelfs indien er sprake is van een ruime arbeidsmarkt. Daarnaast zijn er andere factoren waarmee bij het in kaart brengen van de actuele arbeidsmarktsituatie rekening gehouden dient te worden, waaronder de non-respons bij de enquête, de herintreding van vrouwen, de uitwijkmogelijkheden voor afgestudeerde apothekersassistenten en de substitutiemogelijkheden voor werkgevers. Hoewel de laatste twee factoren van relatief gering belang zijn voor de arbeidsmarktsituatie van apothekersassistenten, kunnen ze toch van significante invloed zijn op eventuele tekorten en overschotten ${ }^{5}$.

5. Zie Van Smoorenburg en Van der Velden (1996). 
Om de kwaliteit van de resultaten van de enquêtes van de SBA te bepalen, kunnen deze worden vergeleken met andere indicatoren die de arbeidsmarktsituatie van apothekersassistenten in beeld brengen. Voor het kenschetsen van de actuele arbeidsmarktsituatie van apothekersassistenten zal gebruik worden gemaakt van de expertise en de databestanden die bij het ROA reeds aanwezig zijn. Daarbij kan gebruik worden gemaakt van arbeidsmarktindicatoren die in het kader van het Informatiesysteem Onderwijs-Arbeidsmarkt worden opgesteld en van de informatie die verkregen uit de databestanden van een aantal recente jaren van de grootschalige schoolverlatersenquête $R U B S^{6}$. De resultaten van de SBA-enquêtes zullen derhalve vergeleken worden met de werkloosheid onder schoolverlaters die een opleiding tot apothekersassistent hebben afgerond en met de omvang van de arbeidsmarktinstroom van gediplomeerde schoolverlaters van de opleiding tot apothekersassistent. Hierbij dient beseft te worden dat de arbeidsmarktsituatie voor apothekersassistenten niet alleen bepaald wordt door een tekort of overschot op de arbeidsmarkt voor apothekersassistenten, maar ook door bijvoorbeeld het loon, de duur van de baan (vast of tijdelijk), de mogelijkheden voor het volgen van een cursus of bedrijfsopleiding, etc.

3. Kan op basis van de enquêtes een eventueel toekomstig tekort of overschot op de arbeidsmarkt voor apothekersassistenten voorzien worden?

Voor het opstellen van arbeidsmarktprognoses voor apothekersassistenten zijn er gegevens nodig van de verschillende vraag- en aanbodcomponenten die deel uitmaken van het Informatiesysteem Ondenwijs-Arbeidsmarkt dat door het ROA is ontwikkeld. Deze componenten hebben betrekking op enerzijds de landelijke prognoses van het aantal baanopeningen voor nieuwkomers op de arbeidsmarkt bestaande uit de verwachte uitbreidingsvraag (de werkgelegenheidsontwikkeling) en de verwachte vervangingsvraag (uitstroom voor zover opgevuld door nieuwkomers), en anderzijds de prognoses van de arbeidsmarktinstroom van schoolverlaters van met name de opleiding tot apothekersassistent. Op basis van deze onderliggende ontwikkelingen kan de verwachte toekomstige arbeidsmarktsituatie van apothekersassistenten in kaart worden gebracht. Deze stromenaanpak heeft als belangrijk voordeel dat de relevante vraag- en aanbodfactoren expliciet in de analyse worden betrokken.

In het onderzoek zal worden nagegaan in hoeverre de resultaten van de SBA-enquêtes inpasbaar zijn in de bovengenoemde componenten van het prognosemodel dat door het ROA wordt gebruikt. Daarbij wordt ook onderzocht of er verantwoorde prognoses kunnen worden opgesteld op basis van de resultaten van de SBA-enquêtes.

In de navolgende hoofdstukken komen de bovenstaande vragen achtereenvolgens aan de orde. Hoofdstuk 2 van dit rapport gaat in op de technische en inhoudelijke aspecten van de enquêtes van de SBA. Vervolgens laat hoofdstuk 3 zien in hoeverre de resultaten van de enquêtes actuele tekorten en overschotten weerspiegelen op de

6. 'RUBS' staat voor Registratie van de Uitstroom en Bestemming van Schoolverlaters. 
arbeidsmarkt voor apothekersassistenten, onder meer door deze resultaten met arbeidsmarktgegevens uit andere databronnen te vergelijken. Bovendien worden in hoofdstuk 3 de mogelijkheden besproken om de resultaten van de enquêtes in een model voor arbeidsmarktprognoses te gebruiken. In hoofdstuk 4 worden de conclusies en de daaruit volgende aanbevelingen van het rapport weergegeven. 


\section{Opzet en vraagstelling van de enquêtes}

Voor de beoordeling van de opzet en de vraagstelling van de postenquêtes voor de vacatures onder openbare apotheken en de arbeidsmarktinstroom van apothekersassistenten wordt gebruik gemaakt van de Total Design Methode (TDM) van Dillman $(1978)^{7}$. Volgens Dillman moeten de verschillende onderdelen van een postenquête een geheel vormen, en elkaar versterken in het bewerkstelligen van een positieve beeldvorming over het onderzoek dat middels de enquête wordt uitgevoerd. De verschillende onderdelen van het onderzoek betreffen de vragenlijst, de begeleidende brief en de verdere onderzoeksprocedure. Deze onderdelen moeten met elkaar in overstemming zijn om een zo hoog mogelijk respons te verkrijgen. Hierbij moet aandacht worden besteed aan vier aspecten, namelijk de beloning van de respondent, de kosten voor de respondent ${ }^{8}$, de vertrouwensrelatie tussen respondent en onderzoeker, en het houden van herhalingsronden van de enquêtes. In dit hoofdstuk zal er niet worden ingegaan op de details in de concrete implementatie van de TDM, die door Dillman uiterst gedetailleerd is beschreven, maar zullen de enquêtes worden getoetst op een aantal belangrijke en voor de SBA ter zake doende hoofdpunten van de TDM.

\section{Vacature-enquête onder openbare apotheken}

Jaarlijks enquêteert de SBA meer dan 1400 apotheken met betrekking tot het huidige en het verwachte aantal vacatures. De vragen uit de enquête van 1996 zijn in bijlage 1 opgenomen. In deze evaluatie worden met name de eerste twee vragen uit de vacature-enquête en de begeleidende brief met bijlagen volgens de bovengenoemde TDM getoetst. De overige vragen hadden geen directe betrekking op het aantal vacatures in de openbare apotheken en wisselden bovendien van jaar tot jaar, omdat ze betrekking hadden op een actueel onderwerp van het betreffende jaar. De respons is vanaf $1993(71 \%)$ dalende, maar daalde vooral sterk in 1996: van $56 \%$ in 1995 naar $33 \%$ in 1996 (zie ook hoofdstuk 3). Deze respons is zeer laag ten opzichte van de respons van ongeveer $80 \%$ gedurende de laatste jaren bij de vacature-enquête van het Centraal Bureau voor de Statistiek (CBS) onder alle bedrijven van Nederland (zie ook Van Bastelaer en Laan, 1994). Dit lijkt te wijzen op een relatief slechte opzet en vraagstelling van de vacature-enquête van de SBA. Dit temeer doordat er een sterkere vertrouwensrelatie mag worden verwacht tussen apothekers en de SBA dan tussen het

7. Zie ook Hox e.a. (1984) voor toepassingen van de TDM in Nederland.

8. De begrippen 'beloning' en 'kosten' moeten hier in brede zin worden opgevat. Onder beloning wordt onder meer verstaan de waardering voor het bijdragen van de respondenten aan het welslagen van de enquête, waardoor de respondenten het gevoel krijgen dat zij belangrijk zijn. Verder kan een verslag van de bevindingen in het vooruitzicht worden gesteld, en moet de vragenlijst zo verzorgd en interessant mogelijk worden gemaakt. Onder kosten wordt onder meer verstaan het verkleinen van de (gedeeltelijk psychologische) inspanning voor de respondenten om de vragenlijst te beantwoorden en te retourneren, bijvoorbeeld door een heldere formulering van de vragen en het bijsluiten van een antwoordenveloppe. 
gemiddelde bedrijf in Nederland en het CBS.

Hoewel de aan de apotheker gerichte brief op officieel briefpapier is opgesteld en een datum vermeldt, hetgeen responsverhogend werkt, zou de respons verder verhoogd kunnen worden door de naam en het adres van de geadresseerde op de brief te vermelden. Daarnaast is het onderwerp van de brief niet voldoende duidelijk aangegeven. De omschrijving 'diverse bijlagen' is te vaag en geeft het werkelijke doel van de brief, namelijk het invullen en opsturen van de vacature-enquête, niet goed weer. Bovendien wordt in de begeleidende brief te weinig de relevantie onderstreept van het invullen en opsturen van de enquête door de geadresseerde. De bijgevoegde resultaten van de enquêtes uit de voorgaande jaren geven weliswaar een beeld van het aantal vacatures onder apotheken van 1992 tot en met 1995, ze zijn echter niet eenvoudig te interpreteren door de apotheker. Een belangrijke tekortkoming van de vacature-enquête is de onduidelijkheid over de invloed van de non-respons op het aantal vacatures. Door het ontbreken van non-respons-gegevens zijn de resultaten van de enquête ook voor arbeidsmarktonderzoekers moeilijk te interpreteren (zie hoofdstuk 3$)^{9}$.

Voorts wordt in de begeleidende brief gemeld dat er CAO-aanpassingen zijn, die naar later blijkt slechts betrekking hebben op de 36-urige werkweek (zie vraag 3 van de enquête). Het blijft onduidelijk welke CAO-aanpassingen bedoeld worden, en hoe belangrijk deze aanpassingen zijn. Het toevoegen van brochures (in de vorm van bijlagen) leidt de aandacht van het primaire doel van de brief af, terwijl deze brochures bovendien geen verband hebben met de af te nemen enquête. Het waarborgen van de anonimiteit van de apothekers is belangrijk, maar de tekst hierover trekt door het onderstrepen van de betreffende zinnen onevenredig veel aandacht.

Bij de brief aan de apothekers is een antwoordenvelop met voorbedrukt antwoordnummer gevoegd om het verzenden van het enquêteformulier voor de respondent zo eenvoudig mogelijk te maken. Dit heeft een responsverhogend effect. Het enquêteformulier is echter vastgeniet tussen de andere bijlagen, hetgeen juist niet uitnodigt het enquêteformulier in te vullen en te verzenden. Volgens de TDM moeten de begeleidende brief en de vragenlijst bij voorkeur dubbelgevouwen in een A5-enveloppe aan de geadresseerde worden verstuurd met een kaartje waarmee de respondent om een samenvatting van het onderzoek kan vragen.

Om de respons te verhogen moet de verzending midden in een normale werkweek vallen, dat wil zeggen een week zonder feestdagen en vakanties. Na één week moet volgens de TDM een briefkaart worden verstuurd met dank aan de apothekers die de enquêteformulieren hebben geretourneerd en een milde herinnering aan de overige apothekers. Na drie weken moet er een tamelijk dringend gestelde herinnneringsbrief

9. Non-respons-onderzoek zou bijvoorbeeld eenmalig door middel van een telefonische enquête kunnen worden uitgevoerd (zie Van Smoorenburg e.a., 1995). 
met een vragenlijst en een antwoordenveloppe worden verstuurd. Na vierenhalve week moet volgens de TDM een telefonische herinnering volgen met het doel eventuele onduidelijkheden omtrent de enquête weg te nemen. Indien nodig kan er dan weer een nieuwe vragenlijst worden toegestuurd.

Voorts kan de respons op de vacature-enquête worden verhoogd door de lay-out van de vragen en de vraagstelling te verbeteren. De respondent moet meer worden uitgenodigd de gestelde vragen te beantwoorden door bijvoorbeeld de mogelijke antwoorden onder de vragen te weer te geven in hoofdletters en de structuur die in de vragenlijst is aangebracht met behulp van de lay-out te ondersteunen. Indien bijvoorbeeld de eerste vraag met NEE wordt beantwoord kunnen de vragen 1.a. tot en met 1.d. worden overgeslagen. Dit zou voor de respondent onmiddellijk duidelijk moeten zijn. Bovendien zijn de vragen 1.c. en 1.d. niet scherp gesteld. Als er een vacature is waarvoor het arbeids- of uitzendbureau is ingeschakeld, dan is er vanzelfsprekend nog geen resultaat, omdat de vacature nog bestaat. Indien de relevantie van het arbeidsbureau of uitzendbureau voor de bemiddeling van apothekersassistenten moet worden nagegaan, kan beter worden gevraagd naar de rol die zij gespeeld hebben bij reeds vervulde vacatures ${ }^{10}$.

Een belangrijk punt van verbetering voor de vacature-enquête betreft de interpretatie van het vacaturebegrip. Het is voor de respondent niet duidelijk of er een vacature bestaat als op het moment van het invullen van de enquête reeds bekend is dat deze vacature direct of binnen afzienbare tijd wordt vervuld. Het is bijvoorbeeld denkbaar dat een apothekersassistent gaat vertrekken of al is vertrokken en dat de vervanger al bekend is, maar nog niet in de nieuwe baan is begonnen. In de vacature-enquête van het CBS wordt de respondent expliciet duidelijk gemaakt dat in dit geval sprake is van een vacature (Van Bastelaer en Laan, 1994), hetgeen in de enquête van de SBA niet wordt gedaan. Elke baan die opnieuw wordt vervuld gaat feitelijk gepaard met een vacature (zie ook De Grip, e.a., 1994), ook al is deze vacature van zeer korte duur. Bovendien is in de SBA-enquête onduidelijk hoe een vacature geïnterpreteerd moet worden die binnen twee maanden wordt verwacht. Als een apotheker namelijk een vacature binnen twee maanden verwacht, is het niet meer dan vanzelfsprekend dat de apotheker reeds op zoek is naar een apothekersassistent voor deze aanstaande vacature door bijvoorbeeld een advertentie te plaatsen of de vacature te melden bij het arbeidsbureau. Het is voor de apotheker gemakkelijker om antwoord te geven op de vraag of er in het afgelopen jaar vacatures zijn geweest, hoeveel apothekersassistenten er vertrokken zijn, of de vrijkomende banen opnieuw zijn opgevuld, etc. Deze vragen hebben betrekking op objectief vast te stellen feiten in plaats van onzekere verwachtingen, en zijn derhalve gemakkelijker te gebruiken voor onderzoeksdoel-

10. Bovendien wordt de resultaten van de vragen in de SBA-enquête over de bemiddeling van het arbeids- of uitzendbureau niet gerapporteerd in de jaarverslagen van de SBA of in vakbladen (voor zover bekend), zodat onduidelijk is waarvoor deze vragen dienen. 
einden. Als er niettemin vragen over het verwachte aantal vacatures in apotheken worden gesteld, moet duidelijker worden aangegeven wat met een verwachte vacature wordt bedoeld.

Instroom-enquête onder opleidingsinstituten

Jaarlijks houdt de SBA een enquête onder de 30 scholen die de opleiding tot apothekersassistent aanbieden ${ }^{11}$. De apothekersassistenten worden opgeleid op het niveau van zelfstandig beroepsbeoefenaar/ middenkader ${ }^{12}$. De lange opleiding Apothekersassistent duurt drie jaar en valt onder de opleiding Assisterende beroepen in de gezondheidszorg (MBO), waaronder ook de lange opleidingen tot Doktersassistent en Tandartsassistent vallen. Leerlingen die een havo- of vwo-diploma bezitten kunnen eventueel een verkorte tweejarige opleiding tot apothekersassistent volgen, terwijl het bovendien mogelijk is om voor de opleiding tot apothekersassistent staatsexamen af te leggen (zie ook hoofdstuk 3). De werkvelden van apothekersassistenten zijn de openbare en ziekenhuisapotheek, de apotheek van een gezondheidscentrum of van een apotheekhoudende huisarts, en het laboratorium bij de farmaceutische groothandel of de industrie. Naast de reguliere dagopleiding tot apothekersassistent werd in 1996 in het kader van het leerlingwezen door één MBO-school in samenwerking met het Landelijk Orgaan Beroepsonderwijs en Welzijn, de OVDB, een tweejarige opleiding tot apothekersassistent op middenkaderniveau aangeboden. Gedurende deze opleiding werken leerlingen minimaal één dag per week in de apotheek. In het eerste jaar van deze opleiding ligt de nadruk op theorie, terwijl in het tweede jaar de nadruk op de praktijk ligt. Tot 1996 waren er meer scholen die deze opleiding aanboden. Inmiddels bestaat de opleiding tot apothekersassistent in het kader van het leerlingwezen niet meer.

De vraagstelling in de enquête onder opleidingsinstituten is opgenomen in bijlage 2. De vragen betreffen het aantal leerlingen in de diverse schooljaren, het aantal examenkandidaten en het aantal geslaagde leerlingen in het voorgaande jaar. De enquête heeft als doel inzicht te krijgen in het aantal gediplomeerde apothekersassistenten (nieuwkomers) dat op de arbeidsmarkt instroomt. Het is derhalve noodzakelijk dat alle scholen die de opleiding tot apothekersassistent verzorgen, al dan niet in het leerlingwezen, meewerken aan de rapportage van het aantal leerlingen. Ook het aantal leerlingen dat een staatsexamen aflegt is daarbij van belang.

De eenvoudige opzet van de enquête en de relatief eenvoudige aard van de te verzamelen gegevens laat weinig ruimte voor misverstanden in de vraagstelling. Gezien

11. Deze enquête wordt gehouden in samenwerking met de Koninklijke Nederlandse Maatschappij tot bevordering der Pharmacie (KNMP).

12. De navolgende informatie over de opleiding tot apothekersassistent is afkomstig uit de studiegids van het LDC e.a. (1995). Zie verder ook bijv. Linssen (1996). 
de respons van tussen de 90 en $100 \%$ van de scholen (zie de jaarverslagen van de SBA), voldoet de enquête aan het doel om inzicht te krijgen in het aantal leerlingen en het (verwachte) aantal gediplomeerde schoolverlaters. Niettemin blijkt uit de rapportage van de enquêtegegevens in bijvoorbeeld het jaarverslag van de SBA van 1995 (SBA, 1995) dat de aantallen leerlingen in de eerste twee schooljaren niet altijd bekend zijn. Daarnaast is de uitstroom uit het leerlingwezen onbekend en wordt in de rapportage van de enquête in de jaarverslagen niet het aantal schoolverlaters vermeld dat met succes het staatsexamen heeft afgelegd (zie hoofdstuk 3). Gezien het relatief kleine aantal scholen dat een opleiding tot apothekersassistent aanbiedt (ongeveer 25) en het belang dat de scholen hebben bij een goed inzicht in de arbeidsmarktperspectieven van gediplomeerde apothekersassistenten, moet het door schriftelijke of telefonische herhalingsronden te houden mogelijk zijn om tegen geringe meerkosten een respons van $100 \%$ te verkrijgen.

Voor de continuering van de hoge respons in de toekomst is het raadzaam dat de SBA op de scholen een contactpersoon zoekt, die de enquête elk jaar invult en die persoonlijk op de hoogte van de onderzoeksbevindingen wordt gesteld. Op deze wijze wordt een persoonlijk beroep gedaan op een individuele respondent en wordt bovendien een vertrouwensrelatie met deze respondent opgebouwd. Bij non-respons kan een bepaalde contactpersoon zonder veel moeite schriftelijk of telefonisch worden geattendeerd op het belang van het invullen van de enquête. Daarbij is het noodzakelijk dat het aantal leerlingen en de gediplomeerde apothekersassistenten van de diverse opleidingsinstituten uit de recente enquêtejaren wordt gerapporteerd (zie de jaarverslagen van de SBA). De laatste enquêteresultaten met betrekking tot het aantal gediplomeerde apothekersassistenten moeten niet alleen worden gerelateerd aan de aantallen in het verleden, maar ook aan de vraag naar apothekersassistenten door apotheken en andere werkgevers. Alleen door een confrontatie tussen vraag en aanbod op de arbeidsmarkt voor apothekersassistenten zijn de enquêteresultaten voor opleidingsinstituten en andere belanghebbenden op een zinvolle wijze te interpreteren. Verder is informatie over de verwachte arbeidsmarktperspectieven van de gediplomeerde apothekersassistenten (zie hoofdstuk 3 ) mogelijk heel bruikbaar voor de opleidingsinstituten. 


\section{Interpretatie van de enquête-resultaten}

De vacature-enquête en de instroom-enquête zijn voornamelijk bedoeld om inzicht te krijgen in de actuele arbeidsmarktsituatie van apothekersassistenten. De twee enquêtes die de SBA elk jaar houdt worden geacht een beeld te geven over vraag en aanbod op de arbeidsmarkt voor apothekersassistenten: de enquête onder openbare apotheken met betrekking tot de vraag naar gediplomeerde apothekersassistenten; de enquête onder opleidingsinstituten met betrekking tot de arbeidsmarktinstroom van gediplomeerde apothekersassistenten. In dit hoofdstuk wordt nagegaan hoe bruikbaar de resultaten van de twee enquêtes hiervoor zijn. Bovendien wordt nagegaan of de resultaten van de twee enquêtes kunnen worden gebruikt voor het confronteren van vraag en aanbod. Daarbij wordt ook gekeken naar de mogelijkheden om de resultaten van de twee enquêtes te gebruiken voor het opstellen van arbeidsmarktprognoses voor de vraag en het aanbod van apothekersassistenten en de daaruit voortvloeiende toekomstige arbeidsmarktsituatie.

Interpretatie van de vacature-gegevens

Tabel 3.1 geeft een overzicht van de beschikbare vacature-gegevens voor apothekersassistenten. De vacature-gegevens van de SBA zijn afkomstig uit de steekproeven van de vacature-enquêtes onder openbare apotheken van 1991 tot en met 1996. De vacature-gegevens die de SBA presenteert in onder meer de jaarverslagen zijn om twee redenen niet direct bruikbaar. Ten eerste presenteert de SBA het aantal vacatures in fte's, hetgeen minder bruikbaar is om goed zicht te krijgen op het aantal benodigde arbeidskrachten. Immers, er zijn waarschijnlijk evenveel arbeidskrachten nodig als er part-time vacactures bestaan, omdat het voor een apothekersassistent meestal onmogelijk meerdere part-time functies te combineren, onder meer vanwege de geografische spreiding van de vacatures over verschillende regio's in het land. De aantallen die in tabel 3.1 staan vermeld hebben derhalve betrekking op het totale aantal part-time en full-time vacatures in de steekproeven van de SBA. Naast het aantal waargenomen vacatures wordt daarbij ook het aantal verwachte vacatures in beeld gebracht. Op basis van de in tabel 3.1 gepresenteerde cijfers lijkt het actuele en het verwachte aantal vacatures voor apothekersassistenten tussen 1991 en 1996 een dalende trend te vertonen.

Ten tweede, het is een belangrijke omissie dat de vacature-gegevens van de SBA niet gecorrigeerd zijn voor de non-respons. De SBA gaat er bij de presentatie van de vacature-gegevens blijkbaar vanuit dat de apothekers die niet responderen op de enquêtes geen vacatures hebben. Dit in tegenstelling tot het CBS, dat het aantal waargenomen vacatures corrigeert voor non-respons door middel van lineaire 
ophoging $^{13}$. Om deze reden zijn de vacature-gegevens die in tabel 3.1 vermeld staan achter de bron SBA ROA eveneens gecorrigeerd voor non-respons door lineaire ophoging. De gecorrigeerde vacature-gegevens laten een dalende lijn in het aantal (verwachte) vacatures zien tot en met 1994, een dieptepunt in 1994, en een stijgende lijn vanaf 1994 tot en met 1996. De snelle daling van het aantal vacatures in 1994 ten opzichte van 1993 wordt blijkens het aantal verwachte vacatures in de enquêtemaand ${ }^{14}$ van 1993 voor de daarop volgende 2 tot 6 maanden (zie noot b van tabel 3.1) niet voorzien door de apothekers ${ }^{15}$.

Door de correctie voor non-respons geven de gecorrigeerde vacature-gegevens van de SBA de ontwikkeling in het aantal (verwachte) vacatures waarschijnlijk beter weer dan de ongecorrigeerde vacature-gegevens van de SBA. Dit blijkt ook uit het feit dat de gecorrigeerde vacature-gegevens wat betreft de ontwikkeling van het aantal vacatures tussen 1991 en 1996 beter overeen komen met de ontwikkeling van de aantallen vacatures zoals die door het CBS zijn vastgesteld. De vacature-gegevens van het CBS laten ook een dieptepunt van het aantal vacatures zien in 1994. Bij de vergelijking van het aantal vacatures tussen de gecorrigeerde vacature-gegevens van de SBA enerzijds en de vacature-gegevens van het CBS anderzijds kunnen echter belangrijke vraagtekens worden gezet. De CBS-gegevens hebben namelijk betrekking op een bredere opleidingscategorie dan alleen apothekersassistenten. Bovendien meet de vacatureenquête van de SBA alleen de vacatures voor apothekersassistenten in openbare apotheken ${ }^{16}$. Uit de tabel 3.1 blijkt dat het aantal vacatures in de vacature-enquête van het CBS voor 1994 lager ligt en na 1994 hoger ligt dan het gecorrigeerde aantal vacatures dat volgt uit de vacature-enquête van de SBA. Hiervoor zijn meerdere

13. Deze methode is niet zonder meer juist. Het is denkbaar dat werkgevers die geen vacatures hebben minder responderen, omdat ze door de afwezigheid van vacatures in hun bedrijf minder betrokken zijn bij een vacature-meting (zie ook hoofdstuk 2). Om zekerheid te verkrijgen over de juiste ophoging is uiteraard non-respons onderzoek vereist.

14. De enquêtemaand varieerde tussen de verschillende jaren. Voor de hieruit resulterende verschillen in de waargenomen aantallen vacatures tussen de diverse jaren (zie bijvoorbeeld Van Bastelaer en Laan, 1994) wordt in de interpretatie van de vacature-gegevens niet gecorrigeerd in dit rapport.

15. De daling van het aantal vacatures in 1994 lijkt vooral een gevolg te zijn van het schrappen van de zelfzorgmiddelen uit het AWBZ-pakket per 1 januari 1994, waardoor bijvoorbeeld hoesten vitaminepreparaten niet meer voor vergoeding in aanmerking kwamen. Als gevolg hiervan daalde het aantal voorschriften bij openbare apotheken sterk (gemiddeld met 6,3\%; NIVEL e.a., 1996). Uit de respons op éen van de vragen van de vacature-enquête van de SBA in 1995 blijkt dat er door deze maatregel weliswaar ontslagen zijn gevallen, maar blijkt vooral dat vertrekkend personeel niet vervangen is.

16. Uit het onderzoek van Van Smoorenburg en Van der Velden (1996) blijkt dat onder gediplomeerde apothekersassistenten ongeveer $90 \%$ van de werkende schoolverlaters tussen 1992 en 1994 in een apotheek werkt. 
verklaringen aan te wijzen ${ }^{17}$, waarbij het echter niet eenvoudig is de relevantie van elke verklaring na te gaan. De navolgende discussie in dit hoofdstuk maakt in elk geval duidelijk dat er meerdere oorzaken kunnen zijn voor fluctuaties in het aantal vacatures dat op een bepaald moment wordt vastgesteld.

Tabel 3.1

Vacature-gegevens over apothekersassistenten

\begin{tabular}{|c|c|c|c|c|c|c|c|}
\hline Bron & Variabele & 1991 & 1992 & 1993 & 1994 & 1995 & 1996 \\
\hline $\begin{array}{l}\text { SBA } \\
\text { SBA } \\
\text { SBA }\end{array}$ & $\begin{array}{l}\text { steekproefrespons } \% \\
\text { aantal vacatures } \\
\text { verwacht aantal vac. }\end{array}$ & $\begin{array}{r}66 \\
319 \\
254\end{array}$ & $\begin{array}{r}65 \\
330 \\
230\end{array}$ & $\begin{array}{r}71 \\
198 \\
181\end{array}$ & $\begin{array}{l}63 \\
74 \\
52\end{array}$ & $\begin{array}{l}56 \\
76 \\
51\end{array}$ & $\begin{array}{l}33 \\
48 \\
36\end{array}$ \\
\hline $\begin{array}{l}\text { SBA/ROA } \\
\text { SBA/ROA }\end{array}$ & $\begin{array}{l}\text { aantal vacatures }{ }^{c} \\
\text { verwacht aantal vac. }^{\text {b.c }}\end{array}$ & $\begin{array}{l}483 \\
385\end{array}$ & $\begin{array}{l}508 \\
354\end{array}$ & $\begin{array}{l}279 \\
255\end{array}$ & $\begin{array}{r}117 \\
83\end{array}$ & $\begin{array}{r}136 \\
91\end{array}$ & $\begin{array}{l}145 \\
109\end{array}$ \\
\hline $\begin{array}{l}\text { CBS } \\
\text { CBS }\end{array}$ & $\begin{array}{l}\text { aantal vacatures }{ }^{d} \\
\text { vac. voor schoolverlaters }\end{array}$ & $\begin{array}{l}300 \\
100\end{array}$ & $\begin{array}{l}200 \\
100\end{array}$ & $\begin{array}{l}200 \\
100\end{array}$ & $\begin{array}{l}100 \\
<50\end{array}$ & $\begin{array}{l}200 \\
100\end{array}$ & $\begin{array}{l}200 \\
100\end{array}$ \\
\hline
\end{tabular}

Bron: SBA en CBS vacature-enquêtes 1991-1996

a. Niet gecorrigeerd voor non-respons.

b. In de vacature-enquête van de SBA varieerde de vraagstelling tussen de verschillende jaren met betrekking tot het aantal maanden waarbinnen de vacatures verwacht werden ( 6 maanden in 1991 en 2 maanden in 1995 en 1996).

c. Correctie van SBA-gegevens voor non-respons door lineaire ophoging.

d. Het hier weergeven aantal vacatures heeft betrekking op een aantal opleidingen, waaronder behalve de opleiding voor apothekersassistenten ook de opleidingen voor medisch laboratoriumpersoneel, apothekers, prothesemakers e.d. onder vallen. Het aantal vacatures wordt door het CBS afgerond op honderdtallen.

Aan bestandgegevens over het aantal vacatures kleven meerdere nadelen die de interpretatie van de gegevens bemoeilijken. Ten eerste wordt het vacaturebestand dat op een bepaald moment wordt gemeten beïnvloed door zowel het aantal nieuw onstane vacatures als de duur van openstaande vacatures (zie Van Ours en Hagens, 1987, en Van Ours en Ridder, $1988^{18}$ ). Indien bijvoorbeeld de gemiddelde duur van een vacature afneemt omdat de arbeidsmarkt beter functioneert, dan zal het aantal vacatures dat op een bepaald moment gemeten wordt ook afnemen. In dit geval is er echter geen sprake van een verminderd aantal baanopeningen over een bepaalde periode. Zo is het mogelijk dat de introductie van de Apothekers-Assistenten Banen Bank $\left(A+A=B^{2}\right)$ door de SBA in 1995 de gemiddelde duur van een vacature voor apothekersassistenten heeft doen afnemen vanwege een toename van de bemiddelingsmogelijkheden. In de bestandgegevens van de vacature-enquête van de SBA zou dit tot uiting kunnen komen

17. Behalve de meer strikte vraagstelling in de vacature-enquête van het CBS over het aantal openstaande vacatures (zie hiervoor Van Bastelaer en Laan, 1994), kunnen ook meetfouten in de steekproef van het CBS en een afwijkend meetmoment tussen de CBS- en de SBAenquête debet zijn aan de verschillen.

18. In de genoemde rapporten wordt geconcludeerd dat vacature-enquêtes weinig inzicht bieden in de dynamiek van de arbeidsmarkt, dat wil zeggen in de feitelijke in- en uitstroom van werkenden op de arbeidsmarkt. 
in een afname van het aantal openstaande vacatures op het moment van enquêteren. Overigens wordt er in de vacature-enquête van de SBA wel gevraagd naar de duur van een vacature, maar worden (voor zover bekend) de resultaten hiervan niet gerapporteerd, met uitzondering van de vacatureduur-gegevens van 1991 die wel bekend zijn (zie SBA, 1991a). De gegevens over de vacatureduren kunnen in principe worden gebruikt om stroomcijfers over vacatures te berekenen, hoewel dit niet eenvoudig is en voorzichtig moet worden omgesprongen met de interpretatie van de uitkomsten (zie Van Ours en Hagens, 1987, en Van Ours en Ridder, 1988).

Ten tweede is het ontstaan van nieuwe vacatures sterk afhankelijk van de zogenaamde baan-baan-mobiliteit: bij een hogere baan-baan-mobiliteit valt het aantal vacatures ook hoger uit (zie Van Ours en Hagens, 1987). In een economische opleving zal het aantal werkenden dat van baan wisselt hoger zijn dan in een economische neergang. Door het vertrek van een enkele werkende uit een bepaalde baan naar een nieuwe baan kan daarbij een reeks van opeenvolgende baanwisselingen optreden, hetgeen bekend staat als een vacatureketen (zie De Grip e.a., 1994). Verreweg de meeste vacatures die ontstaan in deze vacatureketens worden niet opgevuld door schoolverlaters. Immers als een nieuwkomer op de arbeidsmarkt (bijvoorbeeld een schoolverlater) een vacature opvult, wordt de vacatureketen beëindigd. Overigens valt te verwachten dat veel vacatures die onmiddellijk of zelfs voor het feitelijk vacant raken van de functie worden opgevuld niet worden gerapporteerd door de betreffende werkgevers (zie ook hoofdstuk 2).$^{19}$ In een economische recessie of of bij een stagnerende werkgelegenheidsgroei is de baan-baan-mobiliteit lager dan gemiddeld. Vacature-ketens zullen dan minder vaak optreden en de vrijkomende vacatures zullen derhalve relatief vaak worden bezet door nieuwkomers op de arbeidsmarkt. Voor inzicht in de arbeidsmarktpositie van instromende gediplomeerde apothekersassistenten moet worden nagegaan welke vacatures voor hen bestemd zijn. Later in dit hoofdstuk wordt ingegaan op vraag en aanbod van nieuwkomers op de arbeidsmarkt. Tabel 3.1 laat zien dat slechts ongeveer eenderde tot de helft van de vacatures voor apothekersassistenten, medisch laboratoriumpersoneel, apothekers, prothesemakers, e.d. uit de vacature-enquête van het CBS geschikt is voor schoolverlaters.

Geconcludeerd kan worden dat vanwege de onzekere invloed van de gemiddelde duur van een vacature, de baan-baan-mobiliteit, de wisselende conjunctuur en de lengte van vacatureketens op vacaturebestand-gegevens, niet al te veel waarde mag worden gehecht aan het aantal vacatures voor apothekersassistenten in tabel 3.1 als indicator voor de actuele arbeidsmarktpositie van apothekersassistenten. Bovendien overschatten de vacatures voor apothekersassistenten de instroommogelijkheden voor schoolverlaters die de opleiding tot apothekersassistent hebben afgerond.

19. Het CBS maakt in zijn vacature-enquête in tegenstelling tot de SBA wel duidelijk wat onder een vacature moet worden verstaan. Banen die vrijkomen door baanwisselingen binnen één bedrijf worden daarbij door het CBS niet als vacature beschouwd. 
De instroom van gediplomeerde apothekersassistenten op de arbeidsmarkt geeft inzicht in het aanbod van nieuwkomers op het arbeidsmarktsegment voor apothekersassistenten. Deze instroom moet worden geconfronteerd met het aantal baanopeningen voor afgestudeerde apothekersassistenten om het tekort of overschot te kunnen bepalen. In tabel 3.2 is het aantal schoolverlaters weergegeven dat in de jaren 1991 tot en met 1996 met goed gevolg het examen voor apothekersassistent heeft afgelegd. In hoofdstuk 2 is reeds ingegaan op de opleiding tot apothekersassistent en het afleggen van een examen via het reguliere dagonderwijs voor apothekersassistent (voorheen MDGO-AA, tegenwoordig MBO-AA) of via het staatsexamen. Uit het aantal gediplomeerde schoolverlaters is de arbeidsmarktinstroom van apothekersassistenten bepaald door rekening te houden met de schoolverlaters die verder studeren of zich om een andere reden niet op de arbeidsmarkt aanbieden.

Tabel 3.2

Instroom van gediplomeerde apothekersassistenten

\begin{tabular}{lrrrrrr}
\hline Variabele & 1991 & 1992 & 1993 & 1994 & 1995 & 1996 \\
\hline Staatsexamen $^{2}$ & 62 & 65 & 63 & 134 & 112 & - \\
Examen MDGO-AA $_{\text {Totaala }^{\mathrm{a}}}$ & 734 & 723 & 720 & 836 & 773 & - \\
geschatte instroom (excl. leerlingw.) $^{\mathrm{b}}$ & 796 & 788 & 783 & 970 & 885 & - \\
\hline
\end{tabular}

Bron: KNMP/ SBA (uit NIVEL e.a., 1996a, tabel 4.1.3.1)

Opm.: '-' = geen gegevens bekend

a. Gegevens zijn door het KNMP vergelijkbaar gemaakt door te corrigeren voor non-respons.

b. Correctie door het ROA op basis van het percentage apothekersassistenten dat zich op de arbeidsmarkt aanbiedt. De vermenigvuldigingsfactor is 0,9 omdat gemiddeld ongeveer $10 \%$ van de gediplomeerde apothekersassistenten tussen 1992 en 1994 zich niet op de arbeidsmarkt heeft aangeboden (Van Smoorenburg en Van der Velden, 1996).

Uit de gegevens van tabel 3.2 blijkt dat in 1994 een opwaartse sprong in het aantal gediplomeerde apothekersassistenten heeft plaatsgevonden ten opzichte van de voorgaande jaren. In 1995 is het aantal gediplomeerde apothekersassistenten weer gedaald ten opzichte van 1994, maar nog altijd aanzienlijk hoger dan in de jaren vóór 1994. Overigens zou voor een compleet beeld van de gediplomeerde apothekersassistenten die op de arbeidsmarkt instromen ook de schoolverlaters van het leerlingwezen meegenomen moeten worden. Gegevens over gediplomeerde apothekersassistenten van het leerlingwezen zijn echter niet beschikbaar ${ }^{20}$.

20. Om een beeld te krijgen van het aantal apothekersassistenten in het leerlingwezen wordt hier vermeld dat het aantal eerstejaars in 1993 en 1994 respectievelijk 123 en 98 was (SBA, 1994a). Gegevens van de OVDB (zie hoofdstuk 2) laten zien dat het aantal apothekersassistenten in het leerlingwezen snel daalt. Navraag bij de OVDB leert dat de opleiding inmiddels niet meer wordt aangeboden door de opleidingsinstituten. 


\section{Confrontatie tussen vraag en aanbod van apothekersassistenten}

Voor de confrontatie tussen vraag en aanbod van apothekersassistenten kunnen de vacature-gegevens van de SBA, naar hierboven is gebleken, niet goed gebruikt worden om een beeld te krijgen van de vraag naar apothekersassistenten. In De Grip e.a. (1994) wordt bovendien aangegeven dat de werkgelegenheidsgroei een betere indicator is voor de (uitbreidings)vraag naar apothekersassistenten dan de vacaturebestandgegevens (zie ook verderop in dit hoofdstuk). Behalve de eerder genoemde argumenten speelt hierbij ook een rol dat in de vacature-enquête van de SBA alleen de werkgevers van openbare apotheken geënquêteerd worden, terwijl een gedeelte van de apothekersassistenten niet in openbare apotheken werkt ${ }^{21}$. Daarnaast moet er rekening mee worden gehouden dat gediplomeerde apothekersassistenten in de praktijk ook in andere beroepen dan het beroep van apothekersassistent gaan werken. Dit is immers van belang voor het vaststellen van de totale vraag naar afgestudeerde apothekersassistenten. Met betrekking tot de instroomgegevens die eerder zijn besproken is al opgemerkt dat deze gegevens goed gebruikt kunnen worden voor een confrontatie tussen vraag en aanbod. Voor de bepaling van het aanbod van apothekersassistenten op de arbeidmarkt moet daarbij wel rekening worden gehouden met de herintreding van vrouwen en met de kortdurig werklozen.

Tabel 3.3 geeft een aantal kencijfers voor de werkgelegenheid en werkloosheid van apothekersassistenten weer. Het aantal werkzame apothekersassistenten dat door het CBS op basis van de Enquête Beroepsbevolking (EBB) wordt waargenomen, blijkt niet geheel overeen te komen met de pensioengegevens van apothekersassistenten (afkomstig van de Stichting Pensioenfonds Medewerkers Apotheken, SPMA) die door de KNMP zijn gebruikt voor het vaststellen van het aantal werkzame apothekersassistenten. Mogelijkerwijs heeft dit te maken met het verschil in meetmoment (zie de noten bij tabel 3.3) tussen de EBB en het databestand van pensioengegevens en met de meetfouten in de steekproef van de EBB. In dit rapport zullen de (meer gedetailleerde) pensioengegevens van apothekersassistenten worden gebruikt voor verdere analyse.

Uit de gegevens van tabel 3.3 blijkt dat de groei van het aantal werkzame personen in 1994 in één keer sterk gedaald is. Voor het totale aantal werkzame apothekersassistenten in openbare en ziekenhuisapotheken valt de groei terug van 716 in 1993 tot 402 in 1994. Voor alleen de openbare apotheken is de daling van de groei nog groter: van 612 in 1993 naar 281 in 1994. Eerder in dit hoofdstuk is al opgemerkt dat dit te wijten lijkt te zijn aan het schrappen van de zelfzorgmiddelen uit het AWBZpakket. Het percentage werkloze apothekersassistenten stijgt gestaag van 2\% in 1991 tot $5 \%$ in 1994. In 1995 stijgt het percentage werkloze apothekersassistenten verder tot $7 \%$. Het percentage werkloze schoolverlaters op het moment van enquêteren stijgt van

21. Zie hiervoor tabel 3.3. Bovendien lijkt postfarmacie steeds belangrijker te worden (zie bijvoorbeeld De Wolf e.a., 1997). 
$1 \%$ in 1994 naar $4 \%$ in 1995 en $6 \%$ in 1996 . Het percentage werkloze apothekersassistenten, dat na het afstuderen meer dan 3 maanden werkloos was, stijgt sterk van $4 \%$ in 1994 naar $13 \%$ in 1995 . De meeste indicatoren van tabel 3.3 wijzen op een aanzienlijke verslechtering van de arbeidsmarktpositie van apothekersassistenten vanaf 1994. Vóór 1994 lijkt de arbeidsmarktpositie van apothekersassistenten (in termen van werkloosheid, zie ook Van Smoorenburg en Van der Velden, 1996) goed te zijn. De hier geconstateerde snelle verslechtering in de arbeidsmarktsituatie van apothekersassistenten in 1994 blijkt overeen te komen met de aanzienlijke daling in het aantal vacatures voor apothekersassistenten bij openbare apotheken in 1994 zoals dat in tabel 3.1 met behulp van de vacature-enquête van de SBA is vastgesteld, ondanks alle eerder genoemde nadelen die de vacature-enquête van de SBA heeft.

Tabel 3.3

Werkgelegenheid en werkloosheid van apothekersassistenten

\begin{tabular}{|c|c|c|c|c|c|c|c|}
\hline Bron & Variabele & 1991 & 1992 & 1993 & 1994 & 1995 & 1996 \\
\hline $\begin{array}{l}\text { CBS } \\
\text { KNMP e.a. } \\
\text { KNMP e.a. }\end{array}$ & $\begin{array}{l}\text { aantal werkzaam } \\
\text { aantal werkzaam } \\
\text { groei in aantal }^{\mathrm{c}} \\
\text { aantal werkzaam } \\
\text { groei in aantal }^{\mathrm{e}}\end{array}$ & $\begin{array}{r}9.000 \\
10.881 \\
- \\
9.186 \\
-\end{array}$ & $\begin{array}{r}14.000 \\
11.534 \\
653 \\
9.737 \\
551\end{array}$ & $\begin{array}{r}13.000 \\
12.259 \\
716 \\
10.349 \\
612\end{array}$ & $\begin{array}{r}14.000 \\
12.661 \\
402 \\
10.630 \\
281\end{array}$ & $\begin{array}{r}- \\
13.254 \\
593 \\
10.789 \\
159\end{array}$ & $\begin{array}{l}- \\
- \\
- \\
-\end{array}$ \\
\hline KNMP e.a. & $\begin{array}{l}\text { aantal werkloos } \\
\% \text { werkloos }\end{array}$ & $\begin{array}{r}239 \\
2\end{array}$ & $\begin{array}{r}323 \\
3\end{array}$ & $\begin{array}{r}539 \\
4\end{array}$ & $\begin{array}{r}717 \\
5\end{array}$ & $\begin{array}{r}962 \\
7\end{array}$ & $\begin{array}{l}- \\
-\end{array}$ \\
\hline $\begin{array}{l}\mathrm{ROA} \\
\mathrm{ROA}\end{array}$ & $\begin{array}{l}\text { \%werkloze schoolverlaters } \\
\text { \%schoolv.>3mnd.werkloos }\end{array}$ & - & $\begin{array}{l}0 \\
1\end{array}$ & $\begin{array}{l}1 \\
3\end{array}$ & $\begin{array}{l}1 \\
4\end{array}$ & $\begin{array}{r}4 \\
13\end{array}$ & $\begin{array}{l}6 \\
7\end{array}$ \\
\hline
\end{tabular}

Opm.: '-' = geen gegevens bekend

a. Totaal aantal werkzame apothekersassistenten over alle sectoren; jaargemiddelden, afgerond op duizendtallen; NIVEL e.a. (1996a), tabel 4.6.1.1.

b. Totaal aantal werkzame apothekersassistenten in openbare en ziekenhuisapotheken en de industrie; per 31 december; NIVEL e.a. (1996), tabel 5.

c. Verschil in aantal werkzame personen onder b vermeld ten opzichte van het voorafgaande jaar.

d. Totaal aantal werkzame apothekersassistenten in openbare apotheken; per 31 december; NIVEL e.a. (1996a), tabel 4.1.1.2.

e. Verschil in aantal werkzame personen onder b vermeld ten opzichte van het voorafgaande jaar.

f. Als percentage van de som van de werkloze apothekersassistenten en het totaal aantal werkzame apothekersassistenten onder b vermeld.

g. Het betreft gediplomeerde schoolverlaters die het jaar ervoor zijn afgestudeerd; het enquêtemoment valt in het jaar dat bovenaan de kolom vermeld staat.

Daarnaast is uit tabel 3.2 gebleken dat de arbeidsmarktinstroom van afgestudeerde apothekersassistenten gedurende de periode 1991-1995 het hoogste was in 1994. Ook dit heeft de arbeidsmarktpositie van afgestudeerde apothekersassistenten (in termen van werkloosheid) in dat jaar aanzienlijk verslechterd. Uit tabel 3.3 blijkt dat er nauwelijks aanwijzingen zijn dat de arbeidsmarktsituatie van apothekersassistenten na 1994 gaat verbeteren. Twee positieve ontwikkelingen betreffende de arbeidsmarktpositie van apothekersassistenten zijn de stijging in de werkgelegenheidsgroei van het totaal aantal werkzame apothekersassistenten in 1995 (593) ten opzichte van 1994 (402) en de in 1996 waargenomen daling van het percentage afgestudeerde 
apothekersassistenten dat meer dan drie maanden na het afstuderen werkloos was tot $7 \%$ ten opzichte van $13 \%$ in 1995 . Het werkloosheidspercentage onder afgestudeerde apothekersassistenten in $1996(6 \%)$ is overigens nog altijd lager dan het gemiddelde van zowel de schoolverlaters met een opleiding voor één van de assisterende beroepen in de gezondheidszorg, waaronder ook de dokters- en tandartsassistenten (7\%), als het totale aantal schoolverlaters (9\%). Dit geldt ook voor het gemiddelde aantal maanden dat schoolverlaters werkloos zijn voordat ze een baan vinden (zie ROA, 1997).

\section{Van enquêtes naar prognoses}

Voor het opstellen van arbeidsmarktprognoses voor apothekersassistenten is een model vereist dat rekening houdt met alle facetten van vraag en aanbod die hierboven genoemd zijn. In hoofdstuk 1 van dit rapport zijn de componenten van dit model van het ROA al uitgelegd, namelijk de uitbreidingsvraag en de vervangingsvraag die tezamen de baanopeningen vormen, en de instroom op de arbeidsmarkt (zie ook ROA, 1997a). In het prognosemodel van het ROA worden landelijke gegevens over de bovengenoemde componenten gebruikt voor voorspellingen over de arbeidsmarktpositie van alle opleidingscategorieën. Het verbijzonderen van geaggregeerde gegevens naar specifieke opleidingstypen (en beroepsgroepen) staat bekend als een top-down-benadering. In de jongste uitgave van de voorspellingen van het door het ROA ontworpen model (zie ROA, 1997b) is de opleiding tot apothekersassistent apart opgenomen.

Tabel 3.4 geeft de voorspellingen voor de periode 1997-2002 van de opleiding tot apothekersassistent weer. Indien de uitbreidingsvraag wordt vergeleken met de werkgelegenheidsgroei van werkzame apothekersassistenten gedurende 1992 tot en met 1995 (593 in 1995), blijkt dat de voorspelling in tabel 3.4 (960 gemiddeld per jaar) aanzienlijk hoger ligt dan de in de afgelopen jaren gerealiseerde groei van het aantal werkenden. Hetzelfde geldt voor de vergelijking tussen de verwachte arbeidsmarktinstroom van apothekersassistenten in tabel 3.4 (1.280 gemiddeld per jaar) en de gerealiseerde arbeidsmarktstroom van apothekersassistenten gedurende 1991-1995 (797 in 1995) die in tabel 3.2 is weergegeven. Gezien de verhouding tussen het totale aantal baanopeningen (1.540) en de arbeidsmarktinstroom van apothekersassistenten (1.280) typeert het ROA (1997b) het arbeidsmarktperspectief van apothekersassistenten als goed. Bovendien verwacht het ROA grote knelpunten in de personeelsvoorziening. Dit lijkt te wijzen op een nieuwe omslag (omgekeerd aan die van 1994) in de arbeidsmarktsituatie van apothekersassistenten. Hoewel dit niet uit de gerealiseerde indicatoren uit tabel 3.3 valt af te lezen, zal de arbeidsmarktsituatie van apothekersassistenten volgens het ROA weer verbeteren, en zal er binnen afzienbare tijd weer een merkbaar tekort aan apothekersassistenten optreden. 
Tabel 3.4

Verwachte instroom en baanopeningen voor de opleiding MBO Apothekersassistenten, 1997-2002

\begin{tabular}{lcc}
\hline Variabele & $\%$ & gemiddeld aantal per jaar \\
\hline uitbreidingsvraag & 5,1 & 960 \\
vervangingsvraag & 3,2 & 580 \\
totaal aantal baanopeningen & 8,3 & 1.540 \\
instroom & 6,6 & 1.280 \\
\end{tabular}

Bron: ROA (1997b)

Met behulp van de pensioengegevens van de apothekersassistenten en de gegevens over de aantallen leerlingen die aan de opleidingsinstituten voor apothekersassistenten in de diverse leerjaren een opleiding volgen, zijn de voorspellingen van het ROA in tabel 3.4 verder te verbeteren. Het gebruik van sector-specifieke informatie voor de voorspellingen van het ROA staat bekend als een bottom-up-benadering, die de eerder genoemde top-down-benadering op een nuttige wijze kan aanvullen. De pensioengegevens kunnen naast andere sector-specifieke informatie worden gebruikt om de voorspellingen van de verwachte uitbreidings- en vervangingsvraag te verbeteren ${ }^{22}$. De instroomgegevens kunnen worden gebruikt om de voorspellingen van de verwachte arbeidsmarktinstroom van apothekersassistenten te verbeteren.

22. Zie Borghans e.a. (1994) voor het gebruik van sector-specifieke informatie in het prognosemodel van het ROA. 


\section{Conclusies en aanbevelingen}

In dit rapport is ten behoeve van de SBA onderzocht wat de waarde is van enerzijds de vacature-enquête onder werkgevers van openbare apotheken en anderzijds de instroom-enquête onder opleidingsinstituten van apothekersassistenten voor het beschrijven van de actuele en toekomstige arbeidsmarktpositie van apothekersassistenten. Daarbij zijn drie onderzoeksvragen beantwoord.

1. Voldoet de opzet en de vraagstelling van de enquêtes aan de heersende inzichten voor het afnemen van dergelijke enquêtes?

Voor de toetsing van de opzet en de vraagstelling in de enquêtes werd verwezen naar de Total Design Methode voor het afnemen van postenquêtes. Gezien de lage respons en de daarmee gepaard gaande tekortkomingen in de opzet en de vraagstelling van de vacature-enquête van de SBA kan worden geconcludeerd dat de vacature-enquête van de SBA in de huidige vorm niet erg bruikbaar is voor het typeren van de arbeidsmarktpositie van apothekersassistenten. De instroom-enquête onder opleidingsinstituten voor apothekersassistenten blijkt daarentegen in de huidige vorm wel zeer bruikbaar te zijn. Daarbij moet wel de kanttekening worden gemaakt dat een $100 \%$-respons onder de opleidingsinstituten voor apothekersassistenten gerealiseerd dient te worden om een volledig beeld te krijgen van de arbeidsmarktinstroom van apothekersassistenten.

2. In welke mate geven de enquêtes daadwerkelijk inzicht in het actuele tekort of overschot aan apothekersassistenten?

Vanwege de onzekere invloed van de gemiddelde duur van een vacature, de baanbaan-mobiliteit, de wisselende conjunctuur en de lengte van vacatureketens op vacaturebestand-gegevens, kan geconcludeerd worden dat niet al te veel waarde mag worden gehecht aan het aantal vacatures voor apothekersassistenten als indicator voor de actuele arbeidsmarktpositie van apothekersassistenten. Bovendien overschat de vacature-enquête voor apothekersassistenten het aantal vacatures dat bestemd is voor schoolverlaters die de opleiding tot apothekersassistent hebben afgerond. Voor de instroom-enquête geldt wederom dat deze zeer bruikbare resultaten oplevert om de actuele (en toekomstige) arbeidssituatie van apothekersassistenten te beschrijven.

3. Kan op basis van de enquêtes een eventueel toekomstig tekort of overschot op de arbeidsmarkt voor apothekersassistenten voorzien worden?

Gezien de verhouding tussen het totale aantal baanopeningen en de arbeidsmarktinstroom van apothekersassistenten typeert het ROA (1997b) het arbeidsmarktperspectief van apothekersassistenten voor de komende jaren als goed. Daarbij verwacht het ROA grote knelpunten in de personeelsvoorziening. Dit lijkt te wijzen op een nieuwe omslag (omgekeerd aan die van 1994) in de arbeidsmarktsituatie van apothekersassi- 
stenten. Met behulp van de pensioengegevens van de apothekersassistenten en de gegevens van de instroom-enquête zijn de voorspellingen van het ROA verder te verbeteren. Het gebruik van sector-specifieke informatie voor de voorspellingen van het ROA staat bekend als de bottom-up-benadering, die de gewoonlijk door het ROA gehanteerde top-down-benadering op een nuttige wijze kan aanvullen. De vacatureenquête van de SBA levert voor deze benadering geen bruikbare resultaten op.

Uit de beantwoording van de bovenstaande onderzoeksvragen volgen drie aanbevelingen voor de Stichting Bedrijfsfonds Apotheken (SBA).

\section{Aanbeveling 1}

De vacature-enquête van de SBA is geen nuttig meetinstrument, omdat de vacatureenquête weinig inzicht geeft in de actuele arbeidsmarktsituatie van apothekersassistenten en omdat de resultaten van de enquête niet gebruikt kunnen worden voor het opstellen van arbeidsmarktprognoses voor apothekersassistenten.

\section{Aanbeveling 2}

De instroom-enquête van de SBA is een nuttig instrument voor het opstellen van arbeidsmarktprognoses voor apothekersassistenten, mits er door middel van de instroom-enquête een volledig beeld verkregen wordt van alle gediplomeerde apothekersassistenten die in een bepaald jaar staatsexamen afleggen, of aan één van de opleidingsinstituten examen afleggen. Daarnaast is het voor het opstellen van arbeidsmarktprognoses noodzakelijk dat de aantallen leerlingen in de diverse leerjaren bekend zijn.

\section{Aanbeveling 3}

Voor het voeren van arbeidsmarktbeleid door de SBA zijn prognoses over de toekomstige arbeidsmarktsituatie van apothekersassistenten noodzakelijk, waarvoor naast de resultaten van de instroom-enquête van de SBA de pensioengegevens van de Stichting Pensioenfonds Medewerkers Apotheken (SPMA) gebruikt zouden moeten worden. 


\section{Literatuur}

Bastelaer, A. van, en J. Laan (1994), The Job Vacancy Survey in the Netherlands, in: J. Muysken (ed.), Measurement and Analysis of Job Vacancies, Avebury, Aldershot, 1994.

Borghans, L., A. de Grip en J. Hoevenberg (1994), De bruikbaarheid van deelmarktinformatie voor het informatiesysteem onderwijs-arbeidsmarkt, ROA-R-1994/13, Maastricht.

CBS (1991, 1992, 1993, 1994, 1995, 1996), Vacature-enquête, Voorburg/ Heerlen.

Dillman, D.A. (1978), Mail and telephone surveys; the Total Design Method, Wiley, New York.

Grip, A. de, P. Meijboom en E. Willems (1994), Vacancies, employment growth and the demand for newcomers on the labour market, in: J. Muysken (ed.), Measurement and Analysis of Job Vacancies, Avebury, Aldershot, 1994.

Hox, J.J. (1984), The postman rings thrice, een onderzoek naar twee kenmerken van Dillman's Total Design Methode voor postenquêtes, Mens en Maatschappij, nr. 59, pp. 189-194.

LDC, Vereniging BVE, COLO, AOC-Raad (1995), Studiegids MBO en Leerlingwezen 1996, Alle opleidingen in het MBO en Leerlingwezen, Ten Brink Meppel bv, Meppel.

Linssen, J.A.C. (1996), Opleiding van apothekersassistenten in beweging, Pharmaceutisch Weekblad, 131(3), p. 83-87.

NIVEL, NZi en OSA (1996), Rapportage Arbeidsmarkt Zorgsector, Deel1: Hoofdrapport, Ministerie van Volksgezondheid, Welzijn en Sport, Den Haag/ Utrecht.

NIVEL, NZi en OSA (1996a), Rapportage Arbeidsmarkt Zorgsector, Deel 2: Tabellenrapport, Ministerie van Volksgezondheid, Welzijn en Sport, Den Haag/ Utrecht.

Ours, J.C. van, en J.S. Hagens (1987), Vacatures in beweging, OSA-werkdocument, nr. W 35, Den Haag.

Ours, J.C. van, en G. Ridder (1988), Vacatureduren in de jaren tachtig, OSA-werkdocument, nr. W 54, Den Haag.

ROA (1997), Schoolverlaters tussen onderwijs en arbeidsmarkt 1996, Statistische Bijlage, ROA-R1997/3B, Maastricht.

ROA (1997a), De arbeidsmarkt naar opleiding en beroep tot 2002, ROA-R-1997/7, Maastricht.

ROA (1997b), De arbeidsmarkt naar opleiding en beroep tot 2002, Statistische bijlage, ROA-R1997/7B, Maastricht.

SBA (1991, 1992, 1993, 1994, 1995, 1996), Jaarverslag, Den Haag.

SBA (1991a), Meting vraag en aanbod apothekersassistenten, vervolg-enquête maart 1991, Den Haag.

SBA (1994a), Om de kwaliteit van het werk, Een overzicht van de activiteiten van de Stichting Bedrijfsfonds Apotheken in 1994, Den Haag.

Smoorenburg, M.S.M. van, en R.K.W. van der Velden (1996), Apothekersassistenten, Risico's van een geprofessionaliseerde vakdeelmarkt, OSA-publicatie D3, Den Haag.

Wolf, P. de, M.H. Spigt en A.A.T. Overgaag (1997), De apothekersassistenten in model, Een simulatiemodel voor de prognose van arbeidsplaats in de openbare apotheken, Faculteit der Bedrijfskunde, vakgroep Strategie en Omgeving, Erasmus Universiteit Rotterdam. 


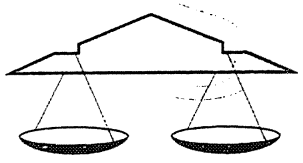

Aan de apotheker.

Den Haag, 26 juni 1996

Betreft: diverse bijlagen

Geachte collega,

De Stichting Bedrijfsfonds Apotheken wendt zich jaarlijks tot $\mathrm{u}$ teneinde inzicht te verkrijgen in de arbeidsmarkt voor apothekersassistenten. De resultaten van de enquête van 1995 treft u hierbij aan.

Wij verzoeken $u$ vriendelijk ook dit jaar weer medewerking te verlenen aan de enquête, nu ook om de eerste gevolgen van de CAO-aanpassingen zichtbaar te maken. De door u verstrekte gegevens worden vertrouwelijk behandeld. Uitsluitend een totaal-overzicht per regio zal worden gepubliceerd. Een antwoordenveloppe is bijgevoegd, deze kan ongefrankeerd worden teruggezonden.

Wij danken u alvast hartelijk voor uw medewerking.

Naast de enquête is bijgevoegd:

* Brochure 'Plezier in je werk' over flexibilisering

* De actuele tekst van de kinderopvangregeling

* Een overzicht van aanstaande SBA-FSN-cursussen

Wij hopen $u$ met deze informatie van dienst te zijn en wensen $u$ en $u w$ medewerkers alvast en goede vakantie toe.

Inmiddels verblijft,

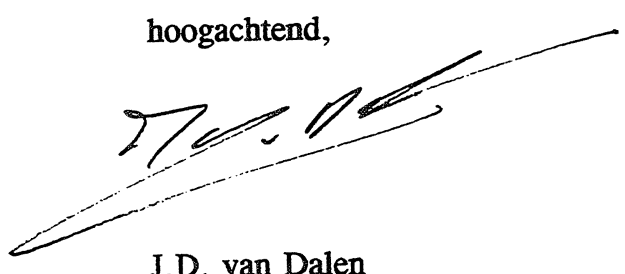

J.D. van Dalen

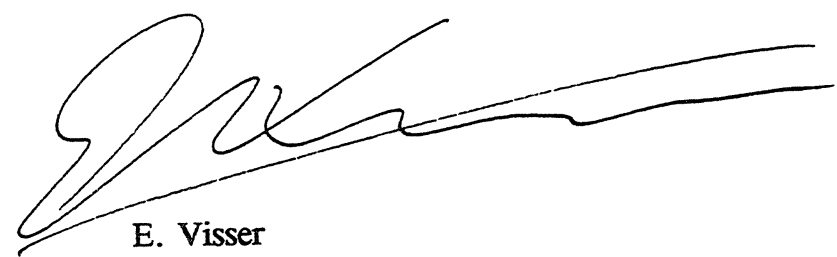

Let op:

adres en telefoon/faxnummers van SBA zijn gewijzigd, onderaan staan de actuele gegevens 
Enquête inzake meting vraag en aanbod apothekersassistenten

1. Heeft u momenteel in uw apotheek één of meerdere vacatures

ja/nee voor apothekersassistenten?
a. Zo ja, welke omvang heeft de vacature uur ... maanden open in uren per week:

$\begin{array}{ccc}\text { vacature } 1 & \ldots & \ldots \\ \text { vacature } 2 & \ldots & \ldots \\ \text { vacature } 3 & \ldots & \ldots\end{array}$

b. Heeft u bij de vervulling van deze vacature(s) problemen? ja/nee Zo ja, welke?

c. Heeft u voor de vervulling van deze vacature(s) een arbeidsbureau ingeschakeld?

Zo ja, wat is hiervan het resultaat?

d. Heeft u bij de vervulling van deze vacature(s) een uitzendbureau ingeschakeld? Zo ja, wat is hiervan het resultaat?

2. Denkt $u$ naast de vacature(s) genoemd in vraag 1 , de komende 2 maanden in uw apotheek vacatures voor een apothekersassistent te krijgen?

a. Zo ja, welke omvang in uren:

$\begin{array}{ccc}\text { vacature } 1 & \ldots & \text { uren } \\ \text { vacature } 2 & \ldots & \text { uren } \\ \text { vacature } 3 & \ldots & \text { uren }\end{array}$

b. Bent $\mathrm{u}$ van plan bij de vervulling van deze nieuwe vacature(s) een arbeidsbureau of uitzendbureau in te schakelen?

Zo nee, waarom niet? 
3. Heeft de a.s. verandering in de CAO (36-urige werkweek) gevolgen voor het aantal assistenten dat $u$ dienst heeft?

Zo ja, met hoeveel uur per week zal uw bezetting uitbreiden?

...... uur

4. Kent $u$ de apothekers-assistenten-banenbank? ja/nee

b. Heeft u wel eens van deze banenbank gebruik gemaakt? ja/nee

c. Bent u van plan er in de toekomst gebruik van te maken? ja/nee

5. Wat is de postcode van de apotheek (desgewenst alleen de eerste 2 of 3 cijfers vermelden indien $u$ dat uit privacy-overwegingen wenst)

\section{GRAAG TERUGZENDEN VOOR 10 JULI A.S.}

Stichting Bedrijfsfonds Apotheken

Carnegieplein 5B

2517 KJ DEN HAAG

tel. (070) 3607698 


\section{Bijlage 2 Vraagstelling aan MDGO-scholen over in- en uitstroom van leerlingen}

1. Uit hoeveel leerlingen bestaat uw eerste leerjaar-AA aan het begin van het schooljaar?

2. a. Uit hoeveel leerlingen bestaat uw tweede leerjaar-AA aan het begin van het schooljaar?

b. Hoeveel leerlingen van dit tweede leerjaar zijn dit jaar nieuw binnengekomen (op HAVO-niveau)?

3. Hoeveel examenkandidaten heeft u dit jaar?

4. a. Hoeveel leerlingen hebben het afgelopen jaar AA-examen gedaan?

b. Hoeveel leerlingen zijn er het afgelopen jaar geslaagd voor het AA-diploma? 